\title{
Laboratory Test Protocol Test Conditions Occurrence
}

National Cancer Institute

\section{Source}

National Cancer Institute. Laboratory Test Protocol Test Conditions Occurrence. NCI

Thesaurus. Code C83064.

An indication or description that the laboratory testing conditions laid out in the study protocol have been met. 